\title{
Aktivitas antibakteri kulit buah karika dieng terhadap Shigella flexneri dan Escherichia coli
}

\section{Antibacterial activity of karika dieng peels againts Shigella flexneri and Escherichia coli}

\author{
Dhiah Novalina $\mathrm{a}^{1{ }^{*}}$, Sugiyarto $^{2}$, Ari Susilowati ${ }^{2}$ \\ 1 Universitas 'Aisyiyah Yogyakarta, Indonesia \\ 2 Universitas Sebelas Maret Surakarta, Indonesia \\ aEmail: dhiah.novalina@gmail.com
}

\section{HIGHLIGHTS}

Ethyl acetat fraction with concentration of $50 \%$ showed the best antibacterial activity

\section{ARTICLE INFO}

\section{Article history}

Received date : July $27^{\text {th }}, 2018$

Revised date : October $28^{\text {th }}, 2018$

Accepted date : December $31^{\text {st }}, 2018$

\section{Keywords:}

Karika;

Peels;

Antibacterial

\section{A B S T R A C T / A B STR AK}

Karika is an endemic plant of Dieng Plateau. The leaf of Karika has been studied to have antibacterial activity against bacteria that cause diarrhea, while the peels are removed or used as a mixture of animal feed. This study aims to determine the antibacterial activity of Karika peels against bacteria that cause poisoning, i.e Shigella flexneri and Escherichia coli. The sample fractionated to obtain the fraction of $n$-hexane and ethyl acetate. The fractions were tested for their antibacterial activity against Shigella flexneri and Escherichia coli by the cup-plate method. The results showed that the ethyl acetate fraction (ethyl acetate 50\%) had the highest inhibition on Shigella flexneri and Escherichia coli compared with another concentration. Based on the study can be concluded that the peels of Karikahas antibacterial activity against Shigella flexneri and Escherichia coli.

Karika merupakan tanaman endemik Dataran Tinggi Dieng. Daun Karika telah diteliti memiliki aktivitas antibakteri terhadap bakteri penyebab diare, sedangkan kulit buah dibuang atau dijadikan campuran pakan ternak. Penelitian ini bertujuan untuk mengetahui aktivitas antibakteri kulit buah Karika terhadap bakteri penyebab keracunan, Shigella flexneri dan Escherichia coli. Sampel difraksinasi untuk memperoleh fraksi n-heksan dan etil asetat. Fraksi diuji aktivitas antibakteri nya terhadap bakteri Shigella flexneri dan Escherichia coli dengan metode sumuran. Hasil penelitian menunjukkan bahwa fraksi etil asetat dengan konsentrasi $50 \%$ memiliki daya hambat tertinggi terhadap Shigella flexneri dan Escherichia coli dibandingkan dengan konsentrasi lainnya. Berdasarkan hasil penelitian disimpulkan bahwa kulit buah Karika memiliki aktivitas antibakteri terhadap bakteri Shigella flexneri dan Escherichia coli.

Copyright (C) 2018 Jurnal Teknologi Laboratorium. All rights reserve 
Dhiah Novalina

Universitas 'Aisyiyah Yogyakarta,

JIn. Ring Road Barat No. 63 Mlangi, Nogotirto, Gamping, Sleman

Yogyakarta, Indonesia.

Email: dhiah.novalina@gmail.com

\section{PENDAHULUAN}

Keracunan dapat berasal dari bahan makanan yang mengandung racun atau akibat bakteri pada makanan tersebut. Keracunan akibat bakteri disebabkan oleh ketidakhiegienisan saat proses pengolahan makanan. Bakteri-bakteri yang dapat menyebabkan keracunan makanan antara lain: Bacillus cereus, Bacillus antrachis, Salmonella sp, Campylobacter jejuni, Shigella sp dan Staphlylococcus aureus. Tingkat kontaminasi bervariasi hingga mencapai 24 - 48\%. ${ }^{1}$ Kontaminasi bakteri pada makanan dan minuman dapat menyebabkan berbagai macam penyakit. ${ }^{2,3}$ Penyakitpenyakit tersebut umumnya mudah menyerang orang yang mengalami penurunan daya tahan tubuh. ${ }^{4}$

Karika (Carica pubescens) merupakan tanaman endemik Dataran Tinggi Dieng, Wonosobo Jawa Tengah. Carica pubescens berkerabat dekat dengan Carica papaya. Ukuran buah Karika lebih kecil dibandingkan pepaya umumnya, bentuk buahnya bulat telur dengan berat $100-150 \mathrm{~g}$, panjang $6-10 \mathrm{~cm}$, dan diameter $3-5 \mathrm{~cm}$. Buah Karika memiliki lima sudut yang memanjang dari ujung hingga pangkal buahnya. Kulit buah Karika berwarna kuning bila sudah masak, permukaannya licin, tebal dan bergetah. ${ }^{5}$ Carica pubescens digunakan sebagai bahan pembuatan selai dan minuman alkohol di Amerika Selatan. Buah yang masih muda dimanfaatkan sebagai obat penyakit cacing dan bahan kosmetik, setelah dikeringkan dan dibuat serbuk. Papain dalam Karika dapat digunakan dalam industri farmasi, makanan dan minuman. Carica pubescens dimanfaatkan sebagai sabun cuci pakaian di Hawai. Di daerah Dieng, Karika dibiarkan terbuang dan jumlahnya melimpah. ${ }^{6}$

Belum ada penelitian tentang Karika di luar negeri, namun telah banyak penelitian tentang aktivitas antibakteri Carica papaya yang merupakan kerabat dekat Karika. Berdasarkan penelitian di luar negeri, kulit buah Carica papaya diketahui memiliki aktivitas antibakteri terhadap $C$. diphtheria, S. pneumoniae, B. substilis, $C$. perfringens. ${ }^{7}$ Pada penelitian lainnya $C$. papaya telah diteliti biji, daun dan akarnya memiliki aktivitas antibakteri terhadap $E$. coli, $S$. aureus, $P$. aeruginosa, S. typhi.,9 Pada penelitian lainnya, $C$. papaya memiliki aktivitas antibakteri terhadap Enterococcus faecalis. ${ }^{10}$

Di Indonesia sudah terdapat beberapa penelitian tentang Karika, misalnya aktivitas antibakteri daun Karika terhadap bakteri penyebab diare,${ }^{11}$ aktivitas antibakteri fraksi etil asetat ekstrak etanol daun Karika terhadap Salmonella typhi secara in vivo dan in vitro. ${ }^{12}$ Pada penelitian lainnya, ekstrak etanol $70 \%$ kulit buah Karika tidak menunjukkan aktivitas antibakteri Salmonella typhii ${ }^{13}$ oleh sebab itu perlu dilakukan pengujian aktivitas antibakteri kulit Karika dengan kemurnian ekstrak yang lebih baik, yaitu berupa fraksi dari ekstrak sampel. Penelitian ini bertujuan untuk mengetahui aktivitas antibakteri ekstrak kulit buah Karika terhadap Shigella flexneri dan Escherichia coli serta untuk mengetahui jenis fraksi terbaik dari ekstrak kulit buah Karika yang berpotensi sebagai antibakteri Shigella flexneri dan Escherichia coli.

\section{BAHAN DAN METODE PENELITIAN}

\subsection{Desain penelitian}

Penelitian ini merupakan penelitian eksperimen dengan melakukan pengujian efektivitas antibakteri yang dimiliki oleh Karika dengan menggunakan rancangan acak lengkap dengan 6 kelompok perlakuan (fraksi n-heksan 50\%, fraksi n-heksan 25\%, 
fraksi n-heksan $12,5 \%$, fraksi etil asetat $50 \%$, fraksi etil asetat $25 \%$, fraksi etil asetat $12,5 \%)$, kontrol positif dan kontrol negatif. Pada masing-masing perlakuan dilakukan 5 kali pengulangan.

\subsection{Lokasi penelitian}

Sampel kulit buah Carica diperoleh dari Koperasi Serba Usaha Carica di kota Wonosobo. Selanjutnya preparasi sampel kulit buah Karika dilakukan di UPT Laboratorium Pusat Universitas Sebelas Maret. Tahap ekstraksi sampel dilakukan di B2P2TOOT Tawangmangu. Tahap fraksinasi ekstrak dan uji antibakteri dilakukan di UPT Laboratorium Pusat Universitas Sebelas Maret.

\subsection{Bahan dan alat penelitian}

Bahan yang digunakan pada penelitian ini antara lain: kulit buah $C$. pubescens yang diperoleh dari Koperasi Serba Usaha Carica di kota Wonosobo. Bahan yang digunakan untuk ekstraksi dan fraksinasi antara lain: n-heksan (Merck), etil asetat (Merck), etanol absolute (Merck). Bakteri uji yang digunakan adalah Shigella flexneri ATCC 25923 dan Escherichia coli EPEC 0111 dari Balai Laboratorium Kesehatan Yogyakarta.

Alat yang digunakan pada penelitian ini antara lain: ekstraktor Perkolasi (Iwaki), gelas beker (Iwaki), timbangan (AT4000 Mettler Toledo), oven (Memmert), petri dish, erlenmeyer (Iwaki), tabung reaksi (Iwaki), waterbath (Haake 15W), Laminair Air Flow, inkubator (P-Selecta), labu erlenmeyer (Iwaki), autoklaf (P-Selecta Presoclave 75), VacumRotary Evaporator R-210 (Buchi Zwitzerland), Vortex Mixer (V-300), UVVisible Spectrofotometer (UV-160 1PC Shimadzu).

\subsection{Koleksi/tahapan penelitian}

\subsubsection{Preparasi Sampel}

Sampel berupa kulit buah Karika diperoleh dari usaha agribisnis Koperasi Serba Usaha (KSU Carica). Sampel kulit buah Karika dicuci bersih dan dikeringkan dalam oven pada suhu $37^{\circ} \mathrm{C}$. Pengeringan kulit buah Karika dilakukan hingga beratnya konstan. Kulit buah Karika yang telah konstan beratnya, selanjutnya diblender hingga berbentuk serbuk.

\subsubsection{Ekstraksi dan Fraksinasi}

Serbuk kulit buah Karika diekstrak menggunakan metode perkolasi. Pelarut yang digunakan untuk ekstraksi adalah etanol $70 \%$. Filtrat yang diperoleh dari ekstraksi selanjutnya dievaporasi di atas waterbath hingga berbentuk pasta. Ekstrak yang telah berbentuk pasta selanjutnya difraksinasi dengan etil asetat dan n-heksan. Pada proses fraksinasi tersebut dihasilkan 2 fraksi, yaitu fraksi etil asetat dan fraksi n-heksan. Fraksi etil asetat dan fraksi n-heksan dipekatkan dengan oven pada suhu $40^{\circ} \mathrm{C}$ hingga berbentuk pasta. ${ }^{9}$ Selanjutnya larutan dari fraksi etil asetat dan $\mathrm{n}$-heksan tersebut digunakan untuk uji aktivitas antibakteri terhadap Shigella flexneri dan Escherichia coli.

\subsubsection{Uji Aktivitas Antibakteri}

Fraksi n-heksan dan etil asetat dari Kulit Karika diuji aktivitasnya terhadap bakteri Shigella flexneri dan Escherichia coli dengan metode Cup-plate Method berdasarkan metode yang direkomendasikan oleh Clinical and Laboratory Standards Institute (CLSI). Metode ini digunakan untuk menentukan diameter zona hambat oleh ekstrak terhadap bakteri yang diujikan. ${ }^{14}$ Inokulum bakteri yang telah disamakan dengan larutan standart MacFarland 0,5, dioleskan secara swab pada media MHA dengan cotton bud steril. ${ }^{15}$ Pada media tersebut dibuat 8 sumuran. Sumuran tersebut terdiri dari kontrol negatif, kontrol positif, perlakuan $n$ heksan konsentrasi $50 \%$, n-heksan konsentrasi $25 \%$ dan $n$-heksan konsentrasi $12,5 \%$, etil asetat konsentrasi $50 \%$, etil 
asetat konsentrasi $25 \%$ dan etil asetat konsentrasi 12,5\%. Pada kontrol negatif, sumuran diisi dengan larutan DMSO yang merupakan pelarut dari ekstrak. Pada kontrol positif digunakan disk antibiotik, dalam hal ini antibiotik ampisilin. Pada perlakuan konsentrasi, sumuran masing-masing diisi $40 \mu \mathrm{L}$ ekstrak (n-heksan dan etil asetat). Selanjutnya biakan diinkubasi selama 24 jam pada suhu $37^{\circ} \mathrm{C}$.

Zona bening yang terbentuk di sekitar sumuran diukur diameternya dengan jangka sorong. Zona bening tersebut mengindikasikan bahwa senyawa kimia pada sampel Karika mampu menghambat bakteri yang diujikan. ${ }^{10}$ Data berupa diameter zona hambat sampel terhadap bakteri selanjutnya dianalisis secara statistik.

\subsection{Analisis data}

Data penelitian berupa diameter zona bening dianalisis secara statistik menggunakan one way Annova. Beda nyata antar perlakuan diuji menggunakan DMRT dengan signifikansi $99 \%$.

\section{HASIL DAN PEMBAHASAN}

Berdasarkan penelitian yang telah dilakukan, diperoleh data kuantitatif berupa diameter zona hambat yang terbentuk akibat penghambatan ekstrak sampel kulit buah Karika terhadap bakteri uji. Kepekaan bakteri uji ditandai dengan besar diameter zona jernih yang terbentuk. Makin besar zona jernih makin peka bakteri uji terhadap senyawa antimikroba tersebut. ${ }^{16}$ Dari uji aktivitas antibakteri diperoleh data diameter zona hambat pada biakan bakteri seperti pada tabel 1 .

Tabel 1. Diameter Zona Hambat pada Biakan Bakteri Uji

\begin{tabular}{lcc}
\hline \multicolumn{1}{c}{ Jenis Fraksi } & \multicolumn{2}{c}{ Diameter Zona Hambat $(\mathrm{mm})$} \\
\cline { 2 - 3 } & S. flexneri & E. coli \\
\hline n-heksan $50 \%$ & 8 & 0 \\
n-heksan $25 \%$ & 6 & 0 \\
n-heksan $12,5 \%$ & 4 & 0 \\
Etil asetat $50 \%$ & 13 & 13 \\
Etil Asetat 25\% & 11 & 10 \\
Etil asetat 12,5\% & 9 & 11 \\
Kontrol negatif & 0 & 0 \\
Kontrol positif & 17 & 18 \\
\hline
\end{tabular}

Fraksi n-heksan memiliki aktivitas antibakteri terhadap S. flexneri, tetapi tidak memiliki aktivitas antibakteri terhadap E. coli pada semua konsentrasi. Aktivitas penghambatan tertinggi fraksi n-heksan terhadap $S$. flexneri terjadi pada konsentrasi $50 \%$ sebesar $8 \mathrm{~mm}$. Pada Tabel 1, diketahui bahwa fraksi etil asetat memiliki aktivitas antibakteri terhadap $S$. flexneri dan E. coli pada semua konsentrasi. Fraksi etil asetat pada konsentrasi $50 \%$ memberikan daya hambat tertinggi terhadap $S$. flexneri dan $E$. coli sebesar $13 \mathrm{~mm}$, selanjutnya daya hambat tertinggi kedua terhadap $S$. flexneri terjadi pada konsentrasi $25 \%$ dan yang memiliki daya hambat terendah terjadi pada konsentrasi $12,5 \%$. Daya hambat tertinggi kedua terhadap $E$. coli terjadi pada konsentrasi 12,55 , sedangkan daya hambat terendah terhadap $E$. coli terjadi pada konsentrasi $25 \%$. Secara umum berdasarkan fraksinya, fraksi etil asetat (konsentrasi $50 \%, 25 \%$ dan $12,5 \%$ ) menunjukkan daya hambat yang lebih baik dibandingkan dengan fraksi n-heksan (konsentrasi $50 \%$, 25\% dan 12,5\%) terhadap bakteri yang diujikan. Hal tersebut ditunjukkan dengan terbentuknya zona hambat pada fraksi etil asetat yang lebih besar dibandingkan dengan fraksi n-heksan. 


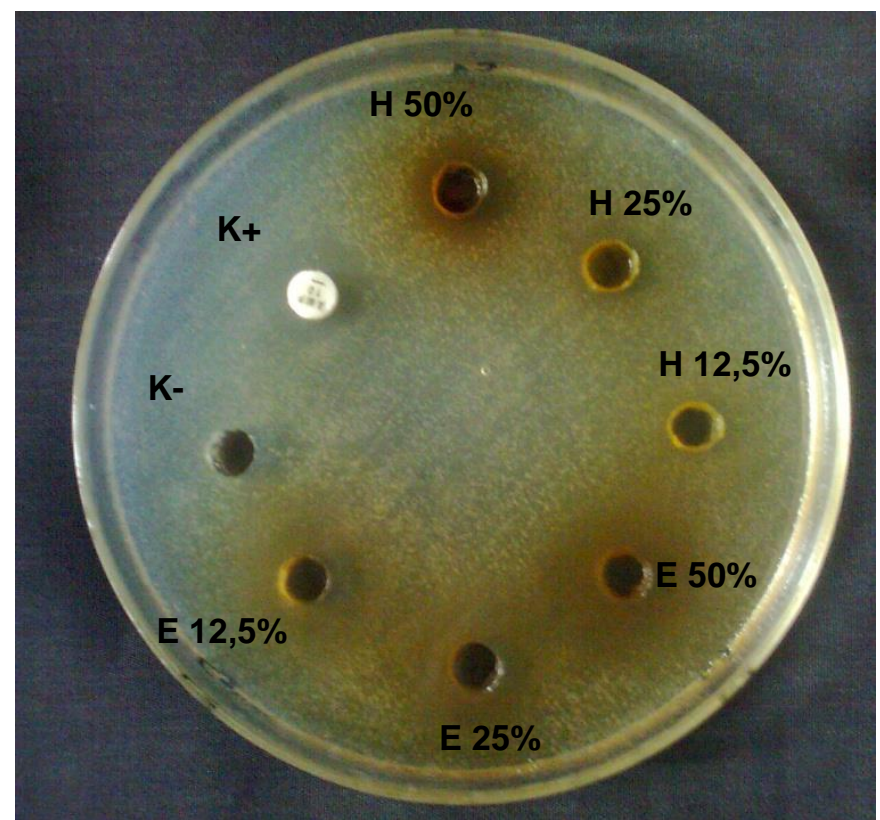

Gambar 1. Zona Hambat Ekstrak Kulit Buah Karika pada Biakan Shigella flexneri Sumber: Novalina (2013)

Pada penelitian ini juga digunakan antibiotik sebagai kontrol positif, yaitu ampisilin. Dari diameter zona hambatnya diketahui ekstrak kulit buah Karika belum mampu melampaui aktivitas ampisilin dalam menghambat $S$. flexneri dan $E$. coli. Namun perlu dilakukan penelitian lanjutan tentang aktivitas antibakteri ekstrak kulit buah Karika pada konsentrasi $100 \%$ terhadap bakteri yang sama, agar bisa dilihat potensinya bila dibandingkan dengan antibiotik.

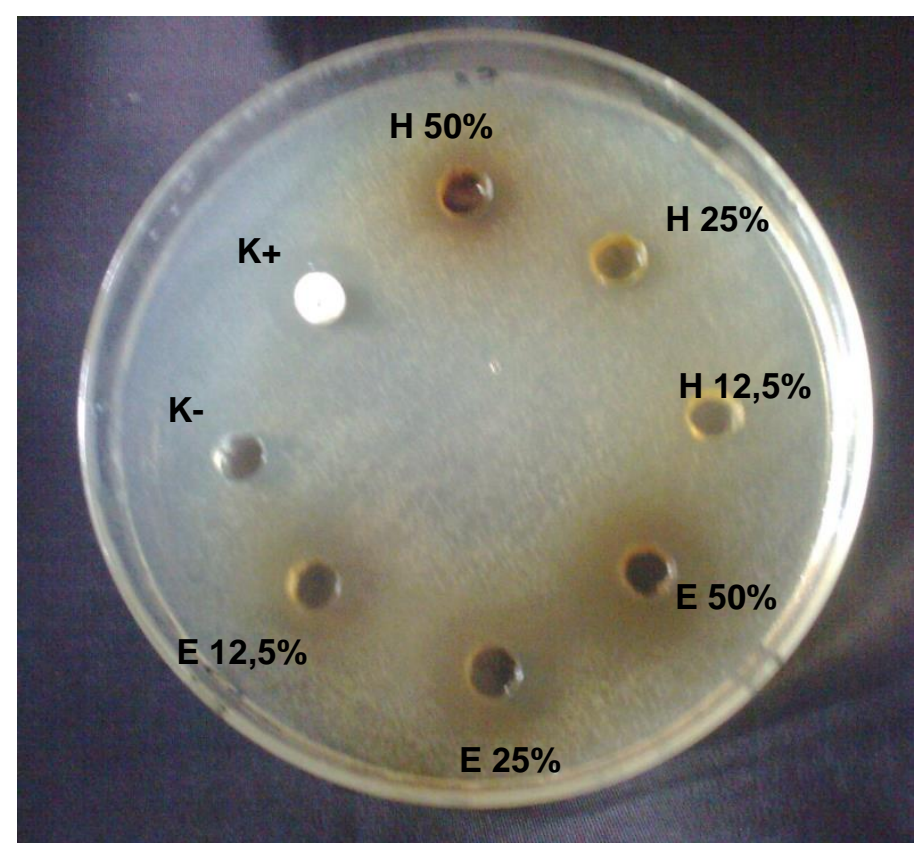

Gambar 2. Zona Hambat Kulit Buah Karika pada Biakan Escherichia coli Sumber: Novalina (2013)

Diameter zona hambat pada masing-masing fraksi dianalisis menggunakan one way Annova. Berdasarkan analisis tersebut diketahui bahwa fraksi n-heksan dengan fraksi etil asetat memberikan pengaruh berbeda secara signifikan terhadap bakteri 
yang diujikan pada ekstrak kulit buah Karika. Hal tersebut menunjukkan bahwa fraksi etil asetat memberikan daya hambat yang tinggi dibandingkan dengan fraksi n-heksan. Pada penelitian lainnya yang serupa, semua ekstrak etil asetat daun dan kulit batang tanaman mangrove menunjukkan daya hambat tertinggi dibandingkan ekstrak petroleum eter, kloroform, etanol dan air. ${ }^{17}$ Penelitian lain menyatakan bahwa ekstrak etil asetat memberikan penghambatan yang relatif tinggi dibandingkan dengan ekstrak n-heksan terhadap bakteri-bakteri penyebab diare yang diujikan. ${ }^{18}$ Pada penelitian lainnya, fraksi etil asetat Satureja graeca menunjukkan aktivitas antibakteri terhadap Staphyllococcus aureus. ${ }^{19}$ Pada penelitian terhadap Tabebuia rosea dan Tarchonanthus camphoratus, ekstrak dari fraksi etil asetat juga menunjukkan aktivitas antibakteri yang baik terhadap Salmonella typhi, Bacillus cereus, Enterococcus faecalis, Escherichia coli. ${ }^{20,21}$ Bahkan pada penelitian lainnya menyatakan fraksi etil asetat dari ko-kultur Streptomyces sp. berpotensi sebagai senyawa antimikrobia dan antikanker yang baik. ${ }^{22}$

Hal ini terjadi berkaitan dengan sifat senyawa fitokimia yang diujikan dengan sifat struktur dinding sel bakteri. Senyawa fitokimia yang terekstrak ke dalam etil asetat bersifat semipolar. Senyawa semipolar tersebut memiliki afinitas yang lebih tinggi untuk berinteraksi dengan dinding sel bakteri yang tidak bersifat absolut hidrofobik dan absolut hidrofilik. Suatu senyawa yang memiliki polaritas optimum akan memiliki afinitas optimum. ${ }^{23}$ Senyawa yang memiliki afinitas optimum akan memiliki afinitas antimikrobia yang optimum, karena untuk dapat berinteraksi antara senyawa antimikrobia dengan bakteri yang diujikan membutuhkan keseimbangan antara hidrofilik dan hidrofobik. Pengamatan di bawah mikroskop elektron aktivitas antibakteri fraksi etil asetat dari Pseudomonas sp. UJ-6 terhadap MRSA (Methicillin-resistant Staphylococcus aureus) ditemukan bahwa fraksi etil asetat dari Pseudomonas sp. UJ6 mampu melisiskan dinding sel dari MRSA. ${ }^{24}$ Selain itu pada penelitian lainnya, fraksi etil asetat biji teratai menunjukkan aktivitas antibakteri terhadap $E$. coli dan $S$. typhimurium meski sudah diberikan perlakuan pemanasan. ${ }^{25}$

\section{SIMPULAN}

Berdasarkan hasil penelitian tersebut disimpulkan bahwa ekstrak kulit Karika memiliki aktivitas antibakteri terhadap bakteri Shigella flexneri dan Escherichia coli. Fraksi etil asetat dari Karika memiliki daya hambat lebih tinggi daripada fraksi $\mathrm{n}$ heksan. Saran bagi penelitian selanjutnya, perlu dilakukan uji aktivitas antibakteri serupa secara in vivo.

\section{UCAPAN TERIMA KASIH}

Ucapan terima kasih disampaikan kepada Prof. Dr. Suranto, PhD, Dr. Edwi Mahajoeno, Staf Laboratorium Galenika B2P2TOOT Tawangmangu.

\section{DAFTAR PUSTAKA}

1. Pracoyo N. E., dan Parwati D.Analisis Mikrobiologik Beberapa Jenis Makanan Jajanan (Moko) di DKI Jakarta. Jakarta: Cermin Dunia Kedokteran; 2006.

2. Siagian A. Mikroba Patogen pada Makanan dan Sumber Pencemarannya. Medan: USU Digital Library; 2002.

3. Coleman ME, Marks HM, Golden NJ, Latimer HK. Discerning Strain Effects in Microbial Dose-Response Data. Journal of Toxicology and Environmental Health. 2004; 67: 667-85

4. Lesmana M.Enterobacteriaceae: Salmonella\&Shigella. Jakarta: Fakultas Kedokteran Universitas Trisakti; 2003.

5. Dewi SK. Analisis Strategi Pengembangan Usaha Industri Kecil Olahan Carica. Departemen Agribisnis Fakultas Ekonomi dan Manajemen. Institut Pertanian Bogor: Bogor; 2009. 
6. Hidayat S. Prospek Pepaya Gunung (Carica pubescens Lenne \& K. Koch) dari Sikunang, Pegunungan Dieng, Wonosobo. UPT Balai Pengembangan Kebun Raya LIPI: Bogor; 2000.

7. Muhamad SAS, Jamilah B., Russly AR and Faridah A. In vitro antibacterial activities and composition of Carica papaya cv. Sekaki/ HongKong Peel Extracts. International Food Research Journal. 2017; 24(3): 976-984.

8. Nirosha $\mathrm{N}$ and Mangalanayaki R. Antibacterial Activity of Leaves and Stem Extract of Carica papaya L. IJAPBC. 2013; 2(3).

9. Peter JK, Kumar Y, Pandey P and Masih H. Antibacterial Activity of Seed and Leaf Extract of Carica papaya var Pusa Dwarf Linn. Journal of Pharmacy and Biological Sciences. 2014; 9(2): 29-37.

10. Wilda Y, Satryani FM, Maemonah S, Badriyah, Christyaningsih J. The Inhibitory Effect of Carica papaya cv. Thailand Leaf Extract to the Growth of Enterococcus faecalis In Vitro. Scholars Journal of Dental Sciences. 2017; 4(6):262-266 .

11. Novalina Dhiah, Sugiyarto, Susilowati A. Aktivitas Antibakteri Ekstrak DaunCarica Pubescens Dari Dataran Tinggi Dieng Terhadap Bakteri Penyebab Diare. El-Vivo. 2013; 1(1): 1-12.

12. Alfiah I. Aktivitas Antibakteri Fraksi Etil Asetat Ekstrak Etanol Daun Karika Terhadap Salmonella typhi secara in Silico dan in vitro. Malang: Jurusan biologi Universitas islam negeri maulana malik ibrahim malang; 2016.

13. Putri Gl dan Nurhayani. Uji Aktivitas Antibaktri Ekstrak Etanol $70 \%$ Kulit Buah Carica (Carica pubescens) Terhadap Bakteri Salmonella typhi. Universitas Muhammadiyah Surakarta: Surakarta; 2018.

14. Puspawati N. Aktivitas Antimikrobia dan Profil Kromatografi Lapis Tipis dari Ekstrak Meniran Merah (Phyllanthus urinaria) dan Hasil Fraksinasinya terhadap Staphylococcus aureus ATCC 25923.Program Pascasarjana Universitas Sebelas Maret: Surakarta; 2011.

15. Ahmed D, Waheed A, Chaudhary MA, Khan SR, Hannan A and Barkaat M. Nutritional and Antimicrobial Studies on Leaves and Fruit of Carissa opaca Stapf Ex Haines. EJEAF Che,. 2010; 9 (10): 1631-1640.

16. Kumala S, Shanny F dan Wahyudi P. Aktivitas Aantimikroba Metabolit Bioaktif Mikroba Endofitik Tanaman Trengguli (Cassia fistula L.). Jurnal Farmasi Indonesia. 2006; 3(2): 97-102.

17. Abeysinghe PD. Antibacterial Activity of some Medicinal Mangroves against Antibiotic Resistant Pathogenic Bacteria. Indian J. Pharm. Sci. 2010;72 (2): 167172.

18. Fitrial $Y$, Astawan M, Soekarto SS, Wiryawan KG, Wresdiyati T, Khairina R. Aktivitas Antibakteri Ekstrak Biji Teratai Terhadap Bakteri Patogen Penyebab Diare. J. Teknologi dan Industri Pangan. 2008;19(2).

19. Boutellaa S, Zellagui A, Baaziz N and Hallis Y.Assessment of Antimicrobial Activity of Ethyl Acetate and n-butanol Extracts from Satureja graeca L. growing in Algeria.Der Pharmacia Lettre. 2016; 8(19):462-465 .

20. Solomon S, Muruganantham N, Senthamilselvi MM. Antimicrobial Activity of Tabebuia rosea (bunga). International Journal of Research and Development in Pharmacy and Life Sciences. 2016; 5(2): 2018-2022.

21. Wetungu MW.,Matasyoh JC, Kinyanjui T.Antimicrobial activity of solvent extracts from the leaves of Tarchonanthus camphoratus (Asteraceae). Journal of Pharmacognosy and Phytochemistry. 2014; 3(1): 123-127.

22. Haque U, RahmanA, Haque A, Sarker AK, Islam AU. Antimicrobial and Anticancer Activities of Ethyl Acetate Extract of Co-culture of Streptomyces sp. ANAM-5 and AIAH-10 Isolated From Mangrove Forest of Sundarbans, Bangladesh. Journal of Applied Pharmaceutical Science. 2016; 6(02):051-055. 
23. Kanazawa A, Ikeda T and Endo T. A novel Approach to Mode of Action of Cationic Biocides Morphological Effect on Bacterial Activity. J. Appl. Bacterial. 1995; 78: 5560.

24. Lee Dae-Sung, Sung-Hwan E, Jae-Young J, Young-Mo K, Myung-Suk L and Young-Man K. Antibacterial Activity of an Ethyl Acetate Extract of Pseudomonas sp. UJ-6 against Methicillin-Resistant Staphylococcus aureus. Fish Aquat Sci. 2013;16 (2): 79-84.

25. Fitrial Y. Aktivitas Antibakteri Ekstrak Etil Asetat Biji Teratai (Nymphaea pubescens Willd) Akibat Pemanasan.Jurnal Pengolahan Hasil Perikanan Indonesia. 2011; 14(1): 43-48. 